\begin{tabular}{|c|c|}
\hline \multirow{2}{*}{$\begin{array}{l}\text { Informing Science: } \\
\text { the International Journal of } \\
\text { an Emerging Transdiscipline }\end{array}$} & $\begin{array}{l}\text { An Official Publication } \\
\text { of the Informing Science Institute } \\
\text { InformingScience.org }\end{array}$ \\
\hline & Inform.nu \\
\hline
\end{tabular}

Volume 20, 2017

\title{
AN ANALYSIS OF THE EFFECTIVENESS OF THE CONSTRUCTIVIST APPROACH IN TEACHING BUSINESS STATISTICS
}

$\begin{array}{ll}\text { Greeni Maheshwari } & \text { RMIT University, Ho Chi Minh City, } \\ & \text { Vietnam } \\ \text { Susan Thomas } & \text { RMIT University, Ho Chi Minh City, } \quad \text { Susan.thomas@rmit.edu.vn } \\ & \text { Vietnam } \\ \text { *Corresponding author } & \end{array}$

\section{ABstract}

Aim/Purpose

The main aim of the research is to examine the performance of second language English speaking students enrolled in the Business Statistics course and to investigate the academic performance of students when taught under the constructivist and non-constructivist approaches in a classroom environment.

Background There are different learning theories that are established based on how students learn. Each of these theories has its own benefits based on the different type of learners and context of the environment. The students in this research are new to the University environment and to a challenging technical course like Business Statistics. This research has been carried out to see the effectiveness of the constructivist approach in motivating and increasing the student engagement and their academic performance.

Methodology A total of 1373 students were involved in the quasi-experiment method using Stratified Sampling Method from the year 2015 until 2016.

Contribution To consider curriculum adjustments for first year programs and implications for teacher education.

Findings The t-test for unequal variances was used to understand the mean score. Results indicate students have high motivation level and achieve higher mean scores when they are taught using the constructivist teaching approach compared to the non-constructivist teaching approach.

Recommendations for Practitioners To consider the challenges faced by first year students and create a teaching ap-

Recommendation proach that fits their needs.

for Researchers To explore in depth other teaching approaches of the Business Statistics course in improving students' academic performance.

Accepting Editor Raafat Saadé | Received: January 16, 2017| Revised: March 15, 2017 | Accepted: May 14, 2017.

Cite as: Maheshwari, G., \& Thomas, S. (2017). An analysis of the effectiveness of the constructivist approach in teaching business statistics. Informing Science: the International Journal of an Emerging Transdiscipline, 20, 83-97. Retrieved from http://www.informingscience.org/Publications/3748

(CC BY-NC 4.0) This article is licensed to you under a Creative Commons Attribution-NonCommercial 4.0 International License. When you copy and redistribute this paper in full or in part, you need to provide proper attribution to it to ensure that others can later locate this work (and to ensure that others do not accuse you of plagiarism). You may (and we encourage you to) adapt, remix, transform, and build upon the material for any non-commercial purposes. This license does not permit you to use this material for commercial purposes. 
Impact on Society The constructivist approach will enable learning to be enjoyable and students to be more confident.

Future Research The research will assist other lectures teaching Business Statistics in creating a more conducive environment to encourage second language English speaking students to overcome their shyness and be more engaged.

Keywords business statistics, constructivist approach, second language English speakers, student motivation, academic performance

\section{INTRODUCTION}

There are different learning theories established based on how students learn. Among these learning theories are Behaviorism learning theory, Cognitive learning theory, and Constructivist learning theory. Each learning theory offers different benefits to the learners, and so the appropriate learning theory can be applied according to the need of the learners. Sometimes, the combination of three learning theories can be adopted to provide optimum learning to the students (Schunk, 1996). The students enrolled in this course are first year students who are new to the university environment. They have entered the university right after the high-school and, hence, face the double challenge of adjusting to the university environment as well as in studying a technical course like Business Statistics. Unlike teaching other theoretical courses in which students can be easily engaged through drama setting and role-playing activities, teaching the Business Statistics course is very challenging for the lecturers because students are less engaged in the classroom. This is one of the major gaps found in the university and this research discusses the constructivist teaching approach as part of the solution to increase students' engagement in learning a technical course where not many creative activities are included.

According to Chen (2003), Behaviorism learning theory is based on Thorndike's stimulus response principle, where learners just respond to stimuli and are passive learners. In this learning theory, the lecturers design the learning environment by breaking the content of the topic into components and then present the information to the students by direct instructions using lectures. Students passively absorb the knowledge which is promoted by repetition and through positive or negative reinforcement. Therefore, Chen concludes in his research that in order for students to learn better, they would require extrinsic motivation, and further argues that behaviorism learning theory is nothing more than acquiring a new behavior.

Cognitive learning theory came with a major shift from traditional behaviorism learning theory, where the focus is directly on the structure and operation of the human mind (Anderson, 2005). Under this learning approach, learners set their goal and are motivated to learn themselves (Lachman, Lachman, \& Butterfield, 1979). Within this teaching approach, the lecturers provide opportunities for the students to connect to the new information. This information processing approach is where the learners process, store, and retrieve the information for later use to transfer and assimilate new information (Chen, 2003).

The constructivist approach was originally founded by Piaget and Bruner based on the belief that existence of cognitive schemes are developed through coordination and incorporated in a person's action on the realities in the world (Wadsworth, 1996). Constructivism can also be considered as a dialogue between the learning theorists and instructional designers, but sometimes they lack the communication between them and, hence, the curriculum is not designed as per the learners' needs (Duffy \& Jonassen, 2013). The curriculum designed based on constructivist approach not only helps the students to engage with the material but also to develop a community of learners. The social constructivism was founded by Vygotsky (1929), wherein it is recognized that learning also happens when an individual is introduced to some learning cultural community where the people share their problems and tasks by getting engaged in a talk socially and later on this learning gets translated into education (Kiraly, 2014). 
Student-centered constructivist approach is based on the belief that learning only occurs when learners are actively involved in a process of knowledge construction as opposed to passively receiving information (Richardson, 1997). It empowers the students to take ownership of their learning, and when they do so, their learning experiences and objectives are enhanced. On the contrary, the constructivist teaching approach focuses on cognitive development and deep learning rather than behaviors or skills. This approach helps the learners to raise questions about their learning, and interpret and defend their ideas and strategies (Fosnot, 2013). These days computers and the internet play an important role and a great source of information to engage learners by fostering communication among the community members and scaffolding their needs by learning from each other (Liang \& Tsai, 2008).

The motivation of students becomes very important, especially when second language learners study technical courses such as Business Statistics in an English medium of instruction. The study done by Sheikh and Mahmood (2014) on secondary school students suggests that the students are motivated the most when they are taught under student-centered approach. It is also found that students who study under student-centered approach work independently, are more motivated, and have higher competency in the subject, and this results in lower anxiety which in turn increase their overall performances in the course (Black \& Deci, 2000). In the class, one of the most important tasks of a lecturer is to stimulate students' interest, motivation, and enthusiasm to study the course and garner the abilities to apply it in real world scenarios (Fensham \& Gunstone, 1994). What stands in the way of many learners is not the lack of ability but a lack of belief in themselves (Mvududu, 2003). Under this approach the learners construct new ideas based on their previous knowledge and focus on making connections between facts which foster new understanding (Fensham \& Gunstone, 1994).

As per Witfelt (2000), the role of the teachers in the constructivist approach is being a facilitator who provides the guidance, encourages the students towards the group work, discovers the abilities of the students, and facilitates the students' work. The constructivist teaching approach is based on the assumption that students and teachers are not the two sides in the learning process, but represent a team which cooperates towards achieving a common goal by overcoming the barriers in the learning process (Fidan \& Duman, 2014). The research done by Summers, Waigandt, and Whittaker (2005) also suggested that when students were taught under student-centered approach they performed better compared to the students who were taught by using traditional teaching methods. The studies have been conducted wherein the students were taught under interactive teaching approach based on technology resources, and it was determined that the students learn more effectively under interactive teaching approach compared to teacher-centered approach (Gomez, 2011). Unlike language or theoretical courses where students can be engaged with role-playing activities, drama, and many other forms of activities, it is very difficult to grab the students attention and keep them engaged in a technical course like Business Statistics. In addition, there also seem to be limited research using constructivist approach in teaching technical courses in higher education institutions. The findings from this research will be able to shed some light in this area.

Most students studying in higher education institutions in South East Asia are second language English speaking students. Compared to the native speakers they are shy to speak and participate in classroom activities because of the language barrier. Hence, it has become a challenge to the lecturers to create a balance between best teaching methodology and student engagement. Therefore, the main objective of the research is to analyze the effectiveness of the constructivist approach in teaching Business Statistics for second language English speaking students in order to increase their engagement and motivation in the classroom and ultimately lead to improvements in their academic performance. This leads to the following research aims which are to find out if:

- There is a difference in the mean grades achieved between second language English speaking students taught under the constructivist approach and non-constructivist approach.

- There is a difference in the motivation level of second language English speaking students taught under the constructivist approach and non-constructivist approach. 


\section{CONCEPTUAL FRAMEWORK}

The constructivist teaching approach means encouraging the students to ask questions, actively involving them in the class activities, continuously reflecting on students' understanding and evaluating their performances (Kim, 2005). The students construct their knowledge guided by the lecturer rather than just receiving the knowledge from the lecturer or directly from the textbook. The latter concept separates the main philosophy of informing science which breaks down information and transferring the knowledge to the clients, which in this case are the students (Cohen, 2009). Instead the constructivist approach compels the students to participate and engage in the classroom compared to traditional teaching approaches (Kim, 2005). The study carried out by An, Parker, Trolian, and Weeden (2016) shows that active learning plays a significant role in students' learning outcomes which is considered as one of major factor that contributes to good teaching practices. The research indicates that the constructivist approach has a positive effect on both students' performance and motivation, as they find learning interesting because it is carried out in a collaborative learning environment (Nayak, 2007). The constructivist teaching approach is based on learning 5E's (Engage Explore - Explain - Elaborate - Evaluate) and is a student-centered approach rather than teachingcentered approach, whereby the students are challenged more on their learning and consequently produce improved meaningful learning (Singer \& Moscovici, 2008). Integrating technology into the curriculum and the classroom also has a positive impact on students understanding the content and engagement in their learning outcomes (Sadik, 2008).

According to Draper (2002), the basic difference between the traditional teaching approach and the constructivist teaching approach is that in traditional teaching approach the lessons usually start as a part of a bigger idea, whilst in the constructivist teaching approach, the bigger idea is conveyed at the beginning of the lesson and expanded further by including the parts. There are several benefits associated with the constructivist teaching approach. Those benefits include actively engaging students versus students who simply absorb the content by following the instruction of a lecturer. Rather than the lecturer disseminating the information to the students, in the constructivist approach, the students are constructing their knowledge with the lecturer acting as a facilitator who is helping them to build the knowledge (Draper, 2002). This gives the students the opportunity to learn their way, interact with peers and the lecturer, and analyze, interpret, and evaluate their learning (Draper, 2002). This approach helps the students enhance their learning experiences and promotes team work. According to Marzano, Pickering, and Pollock (2001), this way of cooperative learning has a strong effect on student achievement. The constructivist approach also helps in building supportive, helpful, trusting relationships of the students with their peers and the lecturers, especially the disruptive students who experience social or emotional problems in school and find it difficult to connect with other students and lecturers (Danforth \& Smith, 2004).

The constructivist approach also acknowledges the social dimension of learning, wherein the students start their learning as students in the class with their classmates and their lecturer. This helps in developing the learning community in the social and personal reflective processes (Powell \& Kalina, 2009). The formal process of reflection helps students as they develop into leaders in their field who learn from their mistakes (Holyoke, 2016). Similarly, the stage of self-reflection in the constructivist approach may also help students to reflect on their learning with their peers or the lecturer in the class which help them learn better.

According to Board (2013), the constructivist process consists of the following stages:

1) Construction of new knowledge on the prior knowledge: The learning process is impacted by the prior knowledge. If the knowledge is built without the learner's prior knowledge, then learners can easily forget the new constructed knowledge. Hence, it is very important for the lecturers to construct the new knowledge into the students' existing mental framework.

2) Concept development through real and authentic problems: The constructivist learning is based on the fact that the learners learn the concepts through real and authentic problems using class- 
room activities which enable them to be actively engaged and subsequently develop the ability to resolve the problems on their own.

3) Constructivist curriculum: It is very important for the lecturer to present the materials based on the prior knowledge of learners, and what the learners are puzzled by. The constructivist curriculum is basically based on the idea of understanding the concepts more deeply and meaningful. The purpose is to generate the curiosity among the students, and so students start posing questions, and subsequently this results in deeper learning.

4) Closure and reflection on students' learning: It is essential to give proper closure to the learning outcomes of the lesson, as it determines the organization and nature of what has been learnt. The stimulus for learning is cognitive conflict and puzzlement, and this involves discussion and attentive listening. The goal of the constructivist approach is to learn together by applying the concept and resolving the puzzling concepts with the help of the peers or the lecturer. In this way, the proper closure can assist the students to comprehend their learning outcomes, especially at the end of the lesson.

\section{METHODOLOGY}

\section{SAMPLING METHOD}

This research adopted quasi experiment method that used a quantitative approach. Stratified Sampling method was used where the population was divided into two separate groups: Group A (students studying under the constructivist approach, which is further divided into subgroups A1 \& A2), and Group B (students studying under the non-constructivist approach which is further divided into subgroups B1 \& B2). Stratified sampling method is used because the researcher wants to focus on a specific group, the group of students studying Business Statistics from a population of students studying all first year courses.

\section{RESPONDENTS}

Respondents are students enrolled in the Business Statistics course from the year 2015 semester 1, 2, and 3 and 2016 semester 1 and 2. All the respondents are second language English speaking students. The total number of students studying diploma and degree involved in this research are 1373. From the total, assessment results of 647 male students and 726 female students were analyzed. Out of the two groups, one group of 405 students were pursuing degree under the constructivist approach (Group A1), and another group of 690 degree students studied under the non-constructivist approach (Group B1). The second group of 138 students pursuing Diploma were taught under the constructivist approach (Group A2) and 140 Diploma students were taught under the nonconstructivist approach (Group B2). For this study the non-constructivist approach is defined as any other approach besides the constructivist approach used by other lecturers in their classroom environment. One of the limitations to this research is that this research analyzed only the Business Statistics course and did not look into the performances of students in other courses.

\section{ANALYSIS}

The data for this research were tabulated from data that is stored in the Grade Center and Course Evaluation Survey (CES). The Grade Center is used by the lecturer to track students' performance. It is located in the Learning Management System of the University which is known as Blackboard. Similarly, the Course Evaluation Survey (CES) is an instrument used by the University to collect valuable feedback from the students at the end of every semester and shared with the respective lecturer. Students also have options to provide narrative comments in the CES. Feedback from the narrative comments is also shared with respective lecturers who have taught the course. The data on student motivation level is also taken from the survey analysis and qualitative comments provided by the students. For example, one question in the CES form that indicates motivation is shown below. 
"The teaching staff in this course motivate me to do my best work."

The research data was analyzed for both descriptive and inferential statistics using Statistical Package for Social Science (SPSS). The hypothesis testing was done at significance level $(\alpha)$ of 0.05 . To determine the effect of the constructivist teaching approach, the analysis on the data was carried out by considering the overall final scores of the Degree and Diploma students from the year 2015 (semester 1, 2 and 3) until the year 2016 (semester 1 and 2).

The data obtained from Grade Centre and CES were collected from the final scores of students taught by the lecturer using the constructivist teaching approach and from the students who studied with other lecturers under the non-constructivist teaching approach. The qualitative comments were provided by 84 students who studied under the constructivist approach from Group A1 and 32 students from Group B1.

\section{RESULTS}

The findings of the inferential statistics show the effect of constructivist teaching on students' mean score between the two groups as presented in Table 1 and Table 2.

Table 1 reveals that the students in Group A1 have a higher mean (68.3) as compared to Group B1 (62.4). In order to test the hypothesis on whether Group A1 performed higher than Group B1, the ttest was used. The value of t-statistics is 4.89 , which is found to be statistically significant at $5 \%$ significance level $(\alpha)$, indicating that the performance of students under Group A1 is higher than the students under Group B1.

Table 1. t-Test: Two-Sample Assuming Unequal Variances for Degree Students (from the year 2015 semester 1, 2 \& 3 until the year 2016 semester 1 and 2)

\begin{tabular}{|l|l|l|l|l|l|l|}
\hline Group & Observations & Mean & $\begin{array}{l}\text { Standard } \\
\text { Deviation }\end{array}$ & t-value & P-Value & Result \\
\hline A1 & 405 & 68.3 & 18.71 & 4.89 & 0.0000006022 & Significant \\
\cline { 1 - 4 } B1 & 690 & 62.4 & 20.3 & & & \\
\hline
\end{tabular}

$H_{0:} \mu_{1}=\mu_{2}$ (There is no difference in the mean score of the degree students taught by the constructivist approach or any other approaches)

$H_{1}: \mu_{1}>\mu_{2}$ (The mean score of the degree students is higher who are tanght by the constructivist approach as compared to other approaches)

Table 2 also indicates similar outcome for Diploma students, where the students in Group A2 have a higher mean (57.3) as compared to students in Group B2 (50.8). The t-test is used to check the hypothesis. The result shows the value of t-statistics is 3.21, is statistically significant at $5 \%$ significance level $(\alpha)$, indicating that the performance of students under Group A2 is higher than the students under Group B2.

Table 2. t-Test: Two-Sample Assuming Unequal Variances for Diploma Students

\begin{tabular}{|l|l|l|l|l|l|c|}
\hline Group & Observations & Mean & $\begin{array}{c}\text { Standard } \\
\text { Deviation }\end{array}$ & t-value & P-Value & Result \\
\hline A2 & 138 & 57.3 & 15.5 & 3.21 & 0.000737873 & Significant \\
\cline { 1 - 3 } 2 & 140 & 50.8 & 18.3 & & & \\
\hline
\end{tabular}

$H_{0}: \mu_{1}=\mu_{2}$ (There is no difference in the mean score of the Diploma students tanght by the constructivist approach or any other approaches)

$H_{1}: \mu_{1}>\mu_{2}$ (The mean score of the Diploma students is higher who are taught by the constructivist approach as compared to other approaches) 
Hence the hypothesis that the scores of both the Degree and Diploma students are higher for those who are taught by the constructivist approach compared to the other non-constructivist approaches, has been retained. Thus, these results indicate that students achieve better when taught using the constructivist approach.

Figure 1 shows that Group A1 Degree students were successful in achieving higher percentage of High Distinction (HD) and Distinction (DI) scores and, also low percentage of failure rates (NN) as compared to Group B1.

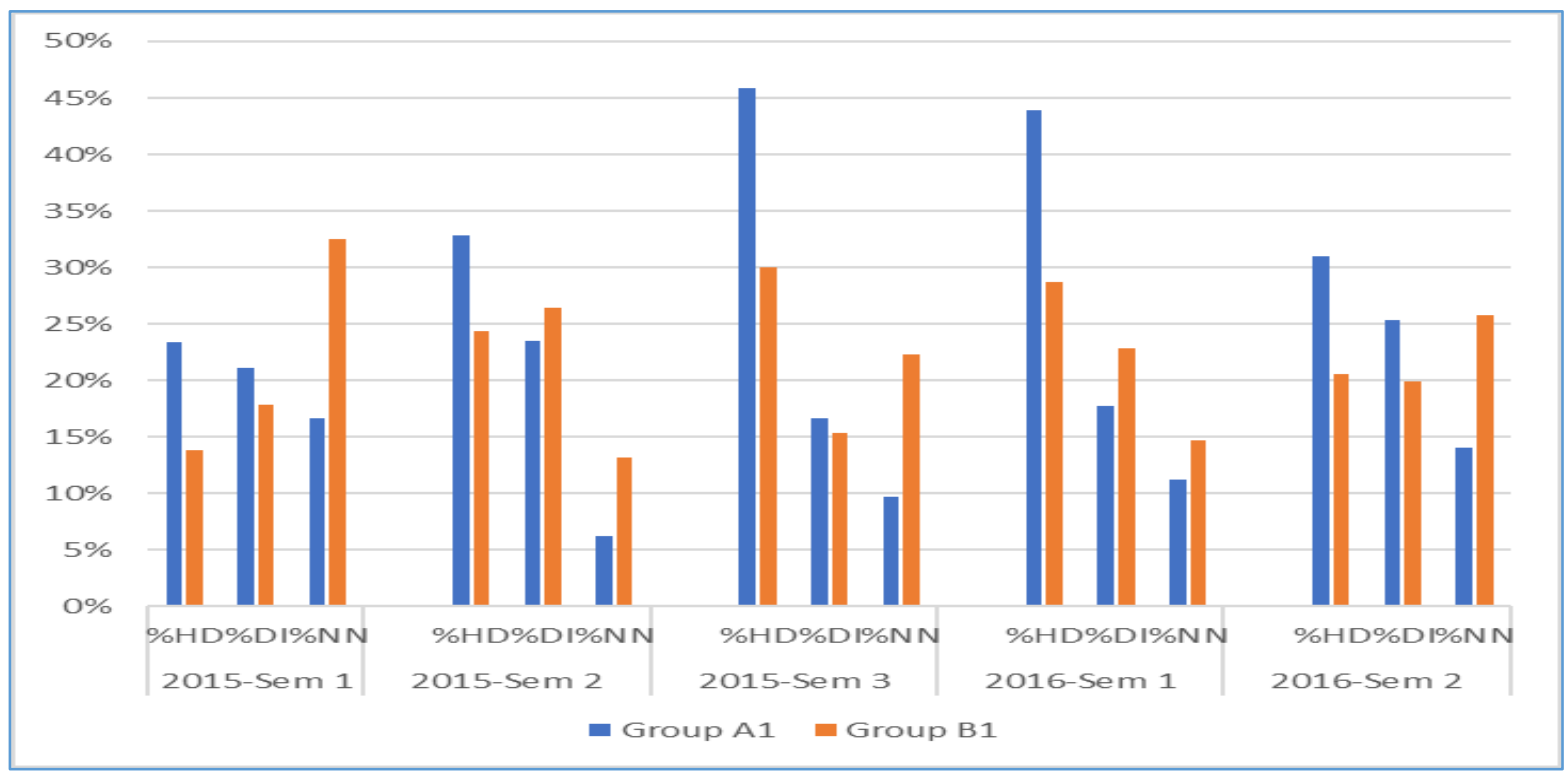

Figure 1: Comparison of HD/DI/NN from the year 2015 semester 1, 2 \& 3 until the year 2016 semester 1 and 2 for Group A1 and Group B1

The Diploma students' biggest problem is the higher failure rate. The comparison of percentage of failure rates between Group A2 and Group B2 is shown in Figure 2. This result prompts that the students taught under Group A2 has almost lower failure rates as compared to Group B2.

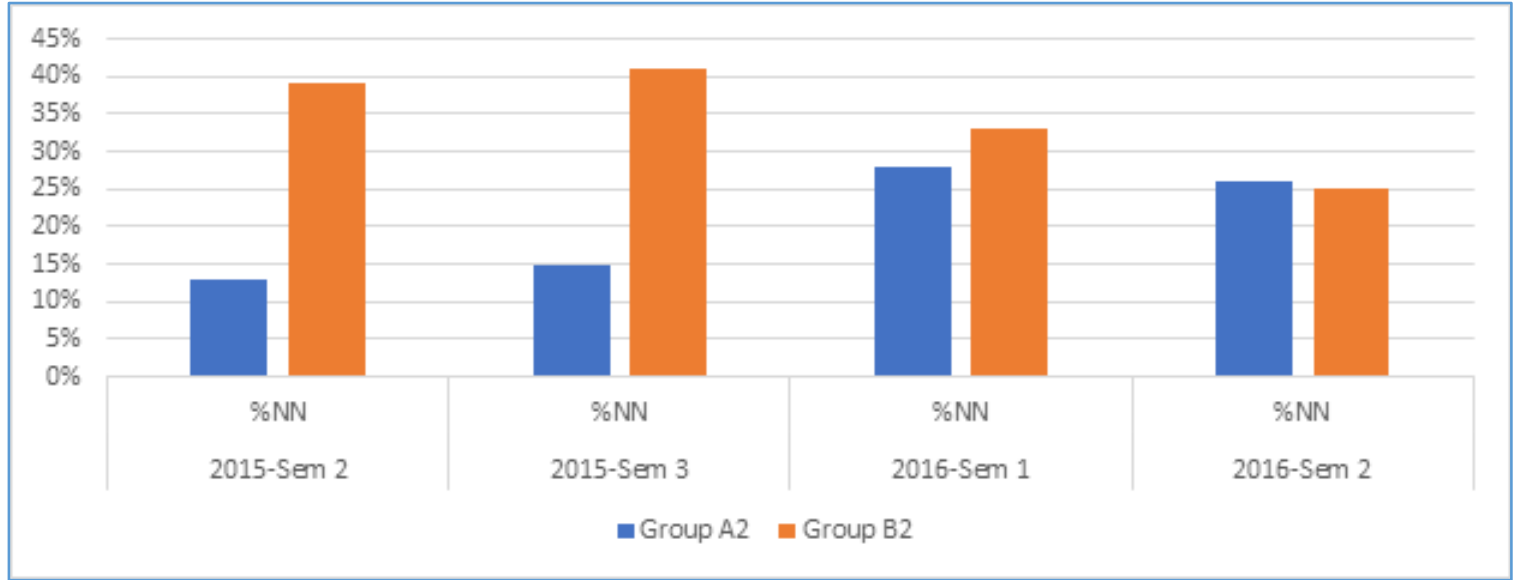

Figure 2: Comparison of percentage failure rates from the year 2015 semester $2 \& 3$ until the year 2016 semester 1 and 2 for Group A2 and Group B2

The results in Table 3 show that if the students are taught with the student-centered constructivist approach, they are more motivated as compared to other students. 
Table 3: Difference in percentage motivation level between Groups A1 \& B1; Groups A2 \& B2

\begin{tabular}{|c|c|c|}
\hline & \multicolumn{2}{|c|}{$\begin{array}{c}\text { \%otivation level of De- } \\
\text { gree students }\end{array}$} \\
\hline Semester & Group A1 & Group B1 \\
\hline 2015 -sem 1 & $80 \%$ & $77 \%$ \\
\hline 2015 -sem 2 & $95 \%$ & $88 \%$ \\
\hline 2015 -sem 3 & $92 \%$ & $88 \%$ \\
\hline 2016 -sem 1 & $97 \%$ & $89 \%$ \\
\hline 2016 -sem 2 & $95 \%$ & $92 \%$ \\
\hline
\end{tabular}

\begin{tabular}{|c|c|c|}
\hline & $\begin{array}{c}\text { \% motivation level of Diplo- } \\
\text { ma students }\end{array}$ \\
\hline Semester & Group A2 & Group B2 \\
\hline 2015 -sem 2 & $83 \%$ & $79 \%$ \\
\hline 2015 -sem 3 & $100 \%$ & $96 \%$ \\
\hline 2016 -sem 1 & $100 \%$ & $92 \%$ \\
\hline 2016 -sem 2 & $93 \%$ & $89 \%$ \\
\hline & & \\
\hline
\end{tabular}

The positive impact of the constructivist approach is not only seen by the increased students' mean score, which has been consistent throughout all the semesters (as shown in Table 4), but the approach is also effective in terms of reduced failure rates, increased high distinction scores, and higher percentage motivational level of students as compared to other teaching approaches (Figures 1 and 2 and Table 3)

Table 4: Comparison of mean scores between Groups A1 \& B1; Groups A2 \& B2 (from the year 2015 semester 1, 2 \& 3 until the year 2016 semester 1 and 2)

\begin{tabular}{|c|c|c|}
\hline & \multicolumn{2}{|c|}{ Mean Scores } \\
\hline Semester & Group A1 & Group B1 \\
\hline 2015-sem 1 & 63.8 & 55.9 \\
\hline 2015-sem 2 & 68.1 & 65.9 \\
\hline 2015-sem 3 & 70.8 & 62.8 \\
\hline 2016-sem 1 & 70.7 & 66.6 \\
\hline 2016-sem 2 & 68.1 & 60.2 \\
\hline
\end{tabular}

\begin{tabular}{|c|c|c|}
\hline & \multicolumn{2}{|c|}{ Mean Scores } \\
\hline Semester & Group A2 & Group B2 \\
\hline 2015-sem 2 & 60.3 & 50.8 \\
\hline 2015-sem 3 & 60.8 & 50.4 \\
\hline 2016-sem 1 & 51.4 & 49.8 \\
\hline 2016-sem 2 & 53.9 & 53.8 \\
\hline & & \\
\hline
\end{tabular}

The qualitative comments from the students obtained from CES also indicated that the constructivist learning approach has positive impact on their learning. These students who were shy in the beginning were able to overcome their shyness and fear by becoming more engaged in the classroom. For example some of the comments made by students are the following:-

Student BP001: "At first, I was really anxious about statistics as I am not confident in my maths skill but after studying this course, I find confidence in solving Statistical problems."

The students also mentioned how the teaching methodology helped them to learn and apply the concepts in real world by the following comments given by the students:-

Student BP002:"Useful knowledge, understand how statistics are used in the reality."

Student BP003; "Lecturer always try her best to teaching in the simplest way to help student understand every concepts in the lecture. Hence $i$ can use it to apply in real world business for any situations."

The students also enjoyed the activities done in the constructivist classroom approach, which are shown by the following comments:

Student BP004 "Do some small games in class --> make the class more interesting and help us easily understand the lesson." 
Student BP005: "This course contains many difficult concepts and problems to solve. Our lecturer has done a great job in delivering information about the course."

\section{DISCUSSION}

As Business Statistics is a first-year course, the students enrolled in this course are directly coming from their high school. They lack the confidence and motivation with a technical course like Business Statistics. It becomes apparent that they are unable to express clearly in the classroom discussion because English is not their first language. Thus, it becomes very challenging and important to get their involvement in the class. This is where the constructivist approach helps in their learning. The constructivist approach enables students to break away from their shyness and allow active engagement in classroom activities.

Following the stages developed by Board (2013) a conceptual framework in the constructivist teaching process was designed for this study, which is shown in Figure 3.

\begin{tabular}{lll}
\hline $\begin{array}{l}\text { Stage 1: } \\
\text { view/Feedback }\end{array}$ & $\begin{array}{l}\text { Stage 2: } \\
\begin{array}{l}\text { Development of } \\
\text { Concepts }\end{array}\end{array}$ & $\begin{array}{l}\text { Stage 3: Guided } \\
\text { Practice }\end{array}$
\end{tabular}

Figure 3: Stages in the teaching process using the constructivist approach

During stage 1. Use of examples reinforces concept checking and engages the students and helps them in their learning.

During stage 2. Explaining the definition of technical terms using simple and non-technical language, and establishing the dialogue with the students to check on the concepts introduced helps in reflecting their understanding.

During stage 3. The aim is to create a supportive environment of collaboration. The students are encouraged to interact with the lecturer and each other. This is facilitated by allocating discussion activities during lectures where students are asked to briefly discuss a concept or idea with other students. The concepts are sometimes also learned by playing games, which engages the students and give them clear understanding about the topic.

The list of activities which are used in constructivist approach involves the following.

- To teach the students about descriptive statistics, the students are asked to collect the data on the age of all the students in the class, and using that they are taught how to construct histograms and various other forms of presenting data. Further the same data is used to teach them the descriptive measures. This hands-on activity helps the students to collaborate and learn together.

- To teach the concept of expected value and hypothesis testing, the dice game is played in the class. The students, after rolling the dice a number of times, determine that the expected value of dice is closer to 3.5 , although not exactly the same due to smaller sample size. Further for hypothesis testing, the students as researchers start with the assumption that the dice is unbiased at the beginning and after each and every student rolls the dice and get the mean number, hypothesis testing procedure is used and it is proved at the end that the dice is unbiased. This play and learn activity helps the students in learning the concept and they can see how this can be applied in the real-world.

- Students learn confidence interval on proportion by again collecting the data on proportion of students wearing spectacles, and this helps them to understand what $95 \%$ of the confidence interval means and how they can apply it in real-life situations. 
- For regression, the students are asked to collect data on their height and weight in the class, considering weight as the dependent variable and height as an independent variable. Further using the excel, the regression output is obtained and this regression output is used to explain the entire regression model and the relationship between the independent and dependent variables.

During stage 4. The class is concluded by summarizing the key points and students are asked several questions about the concepts taught in the class, and the way they answer the questions gives feedback to the lecturer on their level of understanding. Finally, to conclude the content of the class, an online learning application tool "Quizlet" is used and a snapshot of it is shown in Figure 4.

\begin{tabular}{|c|c|c|c|}
\hline $80 \%$ & $\begin{array}{l}\text { At a large state university, } 20 \% \text { of the students are freshmen } 18 \% \\
\text { are sophomores, } 18 \% \text { are juniors, } 15 \% \text { are seniors, and the rest } \\
\text { are graduate students. } \\
\text { What percentage of the students are not freshman? }\end{array}$ & 占 & (4) \\
\hline Median is greater than mean & $\begin{array}{l}\text { For a distribution that is skewed to the left, the relationship } \\
\text { between median and mean is? }\end{array}$ & 占 & $\Leftrightarrow$ \\
\hline 0.05 and 0.09 . & $\begin{array}{l}\text { Suppose that the Blood Alcohol Content (BAC) of students who } \\
\text { drink five beers varies from student to student according to a } \\
\text { Normal distribution with mean } 0.07 \text { and standard deviation } 0.01 \text {. } \\
\text { The middle } 95 \% \text { of students who drink five beers have a BAC } \\
\text { between }\end{array}$ & 今 & $\Leftrightarrow$ \\
\hline $50 \%$ & $\begin{array}{l}\text { The weights of students in a large statistics class vary according } \\
\text { to a Normal distribution with mean } 145 \text { pounds and standard } \\
\text { deviation } 18 \text { pounds. } \\
\text { Approximately what percent of the students weigh less than } 145 \\
\text { pounds? }\end{array}$ & 今 & $\Leftrightarrow$ \\
\hline $95 \%$ & $\begin{array}{l}\text { The distribution of test scores in a large statistics class is } \\
\text { approximately Normal with mean } 75 \text { points and standard } \\
\text { deviation } 7.5 \text { points. } \\
\text { Approximately what percent of the students scored between } \\
60 \text { and } 90 \text { points? }\end{array}$ & 占 & $\Leftrightarrow$ \\
\hline 15 points & $\begin{array}{l}\text { Scores of adults on the Wechsler Adult Intelligence Scale (a } \\
\text { common IO test) follow a Normal distribution. The middle } 95 \% \\
\text { of scores on this test range from } 70 \text { to } 130 \text {. What is the standard } \\
\text { deviation of the test scores? }\end{array}$ & 今 & $\Leftrightarrow$ \\
\hline
\end{tabular}

Figure 4: Snapshot of Quizlet used by the lecturer in the classroom to review the concepts

An online learning tool, "Socrative" is also used in the class to check students' understanding and also to review concepts in stage 1. This is illustrated in Figure 5. Students' concepts were checked on a self-studied topic through a quiz containing 10 questions. This tool helped the lecturer to understand that students had major problem in Questions 8 \& 10, where most of the students struggled. In a class of 35 students, only $30 \%$ and 19\% respectively (as marked with the purple box in the bottom row in Figure 5) were able to answer these questions. Based on students' scores, the lecturer was 
able to pin down the concept where the majority of the students struggled the most and this helped the lecturer to revise in particular those concepts with them again.

\begin{tabular}{|c|c|c|c|c|c|c|c|c|c|c|}
\hline $80 \%$ & & B & C & B & B & A & A & B & B & \\
\hline $30 \%$ & & B & C & A & A & B & C & A & B & C \\
\hline $60 \%$ & & B & C & C & B & B & A & A & A & B \\
\hline \hline $90 \%$ & & B & C & B & B & A & A & A & A & B \\
\hline \hline $70 \%$ & & B & C & C & C & A & A & B & A & C \\
\hline \hline $50 \%$ & & B & C & C & B & B & B & A & A & A \\
\hline \hline $60 \%$ & & B & C & B & C & B & A & B & B & A \\
\hline \hline $50 \%$ & & B & C & B & B & B & B & A & A & A \\
\hline \hline $70 \%$ & & B & C & A & A & A & A & B & A & A \\
\hline \hline $40 \%$ & & B & C & A & B & B & B & A & C & A \\
\hline \hline $60 \%$ & & B & C & B & B & B & A & C & A & A \\
\hline \hline $60 \%$ & & B & C & A & B & A & A & C & A & A \\
\hline \hline $60 \%$ & B & B & A & B & A & A & B & B & C \\
\hline \hline
\end{tabular}

Figure 5: Snapshot of Students' score in a quiz using "Socrative" before lecturer's help

\begin{tabular}{|c|c|c|c|c|c|c|c|c|c|c|}
\hline $100 \%$ & & B & C & B & B & A & A & B & A & B \\
\hline $100 \%$ & & B & C & B & B & A & A & B & A & B \\
\hline $90 \%$ & & B & C & B & C & A & A & B & A & B \\
\hline $100 \%$ & & B & C & B & B & A & A & B & A & B \\
\hline $90 \%$ & & B & C & B & B & A & A & A & A & B \\
\hline $100 \%$ & & B & C & B & B & A & A & B & A & B \\
\hline $90 \%$ & & B & C & B & B & A & A & B & B & B \\
\hline $60 \%$ & & B & C & A & B & A & A & A & & \\
\hline $90 \%$ & & B & C & A & B & A & A & B & A & B \\
\hline $100 \%$ & & B & C & B & B & A & A & B & A & B \\
\hline $100 \%$ & & B & C & B & B & A & A & B & A & B \\
\hline $100 \%$ & & B & C & B & B & A & A & B & A & B \\
\hline $80 \%$ & & C & C & B & B & A & A & B & A & C \\
\hline \multirow[t]{2}{*}{$90 \%$} & & B & C & B & B & A & A & B & B & B \\
\hline & $\%$ & $92 \%$ & $96 \%$ & $85 \%$ & $96 \%$ & $100 \%$ & $100 \%$ & $72 \%$ & $92 \%$ & $92 \%$ \\
\hline
\end{tabular}

Figure 6: Snapshot of the same quiz students had re-taken

Figure 6 is a snapshot of the same quiz students had re-taken after corrections were made. At this time students had constructed their own self-learning. Figure 6 shows the outcome of Questions 8 \& 
10 , in which students who were struggling before, improved with $72 \%$ and $92 \%$ of them were able to understand the concept taught, compared to their previous results which was only $30 \%$ and $19 \%$ respectively (Figure 5).

During stage 5. Some examples from the exercises or from any other sources were given by writing the tasks clearly on the white-board and reminding students that their tasks in the next class will be checked. This forces the students to study outside the class time as well. Also, the topics were assigned in a way that ensures students must do prior preparation before coming to the next class.

It is found in the study that the proposed hypothesis, "The students taught under the constructivist approach have higher mean scores, higher grades, and higher motivation level as compared to their counterparts taught with other teaching approaches" is proven to be true. This is due to the fact that students' learning environment has enhanced their understanding and application abilities in Business Statistics as compared to other students. The main reason which resulted in higher achievement may be due to students' collaboration in the classroom activities, students' self-regulation and motivation, students' ownership in their learning process and the introduction to different learning activities.

\section{CONCLUSION}

This research explored the effectiveness of using the constructivist approach in teaching Business Statistics course for first year second language English speaking students in the University. Many students found it difficult to cope with technical course like Business Statistics and they enrolled in the course with some fear and hesitation. The constructivist approach is a student-centered approach, where the students worked collaboratively in the classroom environment.

The results show improvements in students' academic performance along with their learning abilities. The analysis of the findings show students taught under the constructivist teaching approach in Business Statistics have higher scores compared to the students who are taught under the nonconstructivist teaching approaches. The results also indicate that the students are more motivated in learning Business Statistics when taught under the constructivist approach compared to other students studying under the non-constructivist teaching approaches. This is because students are able to overcome their shyness and interact more actively in class, make sense with the concepts learnt, enjoy a different learning technique, and take ownership of their own learning process. The qualitative comments from students also reflect how learning Business Statistics became easy for them through different forms of activities used in the classroom. The students who were nervous at the beginning of the course became confident as the course progressed and were able to perform better. The results show that the students were consistently performing better when taught under constructivist approach.

The outcome of the research will assist other lectures teaching Business Statistics in creating a more conducive environment to encourage second language English speaking students to overcome their shyness and be more engaged in the classroom. The results of this research may also have similar outcome in other technical courses. Hence, it would be an interesting area to explore further especially in improving students' learning abilities.

From the students' perspective, they can learn how to work collaboratively and take ownership of their studies and make learning more enjoyable. Ultimately both the learning and teaching perspectives in the constructivists approach should be taken into consideration when designing the curriculum for the University. At the same time, it will be useful to share the experience of the constructivist teaching style as part of the University Graduate Certificate in Teaching program. Academics who have vested interest in improving student performance will be able to use their best skills in gauging their second language English speaking students.

However, there are some limitations in the research. The research was carried out only for students enrolled in the Business Statistics course for the year 2015 (semester 1, 2 \& 3) until the year 2016 
(semester 1 \& 2). Other first year courses, such as Business Computing 1, Commercial Law, Marketing Principles, Accounting in Organizations and Society, Prices and Markets, Macroeconomics 1 and Introduction to Management, were not investigated. Investigating the effectiveness of the constructivist approach in all first-year courses will be able to give a clearer understanding towards students' overall performances. In addition the constructivist approach may even draw on other transdisciplinary approaches to resolve a common problem dealing with student retention and transfer of knowledge which other lecturers teaching the first year courses can use.

Secondly, the research did not explore in depth the different teaching approaches used by other lecturers teaching the Business Statistics course. For future research, this research can be expanded with the same cohort of students studying other first year courses in order to understand whether the nature of the course play an important factor in influencing their scores or using different teaching approaches will make any difference to their motivation level and academic performance.

Another limitation is that this research explores the constructivist approaches in a higher education institution for second language English speakers unlike research carried out by other researchers such as Kirschner, Sweller, and Clarke (2006) and Matthews (2003) who explored the impact of the constructivist approach with native speakers studying in high schools. Hence the outcome of the approaches used may give different conclusive results. It will also be useful if more statistical tests like False Discovery Rate (FDR), regression analysis, and correlation can be included. The additional analysis may provide interesting conclusions.

\section{REFERENCES}

An, B. P., Parker, E. T., Trolian, T. L., \& Weeden, D. D. (2016). A holistic approach to estimating the influence of good practices on student outcomes at liberal arts and non-liberal arts institutions. Journal for the Study of Postsecondary and Tertiary Education, 1, 153-175. Retrieved from http://www.informingscience.org/Publications/3446

Anderson, J. R. (2005). Cognitive psychology and its implications. Macmillan.

Black, A. E., \& Deci, E. L. (2000). The effects of instructors' autonomy support and students' autonomous motivation on learning organic chemistry: A self-determination theory perspective. Science Education, 84(6), 740-756.

Board, J. (2013). Learning theory-Constructivist approach. Retrieved from http://education.stateuniversity.com/pages/2174/Learning-Theory-CONSTRUCTIVIST-APPROACH

Chen, C. (2003). A constructivist approach to teaching: Implications in teaching computer networking. Information Technology, Learning, and Performance Journal, 21(2), 17.

Cohen, E. B. (2009). A philosophy of informing science. Informing Science: the International Journal of an Emerging Transdiscipline, 12, 1-15.

Danforth, S., \& Smith, T. J. (2004). Engaging troubling students: A constructivist approach. Corwin Press.

Draper, R. J. (2002). School mathematics reform, constructivism, and literacy: A case for literacy instruction in the reform-oriented math classroom. Journal of Adolescent \& Adult Literacy, 45(6), 520-529.

Duffy, T. M., \& Jonassen, D. H. (Eds.). (2013). Constructivism and the technology of instruction: A conversation. Routledge.

Fensham, P. J., \& Gunstone, R. F. (1994). The content of science: A constructivist approach to its teaching and learning. Psychology Press.

Fidan, N. K., \& Duman, T. (2014). Classroom teachers' possession level of characteristics required by the constructivist approach. Egitim Ve Bilim, 39(174) Retrieved from https://search-proquest-com.ezp02.lirn.net/docview/1554961193?accountid $=143980$

Fosnot, C. T. (2013). Constructivism: Theory, perspectives, and practice. Teachers College Press. 
Gomez, R. (2011). Teaching business statistics courses using an interactive approach based on technology resources. Florida International University.

Holyoke, L. B. (2016). Review of "Building academic leadership capacity: A guide to best practices". Journal for the Study of Postsecondary and Tertiary Education, 1, 177-180. Retrieved from http://www.informingscience.org/Publications/3447

Kim, J. S. (2005). The effects of a constructivist teaching approach on student academic achievement, selfconcept, and learning strategies. Asia Pacific Education Review, 6(1), 7-19.

Kiraly, D. (2014). A social constructivist approach to translator education: Empowerment from theory to practice. Routledge.

Kirschner, P. A., Sweller, J., \& Clark, R. E. (2006). Why minimal guidance during instruction does not work: An analysis of the failure of constructivist, discovery, problem-based, experiential, and inquiry-based teaching. Educational Psychologist, 41(2), 75-86.

Lachman, R., Lachman, J. L., \& Butterfield, E. C. (1979). Cognitive psychology and information processing. Hillsdasle.

Liang, J. C., \& Tsai, C. C. (2008). Internet self-efficacy and preferences toward constructivist Internet-based learning environments: A study of pre-school teachers in Taiwan. Educational Technology \& Society, 11(1), 226-237.

Marzano, R. J., Pickering, D., \& Pollock, J. E. (2001). Classroom instruction that works: Research-based strategies for increasing student achievement. Ascd.

Matthews, W. J. (2003). Constructivism in the classroom: Epistemology, history, and empirical evidence. Teacher Education Quarterly, 30(3), 51-64.

Mvududu, N. (2003). A cross-cultural study of the connection between students' attitudes toward statistics and the use of constructivist strategies in the course. Journal of Statistics Education, 11(3), 1-17.

Nayak, D. K. (2007). A study on effect of constructivist pedagogy on students' achievement in mathematics at elementary level. National Institute of Open Schooling, MHRD, Noida.

Powell, K. C., \& Kalina, C. J. (2009). Cognitive and social constructivism: Developing tools for an effective classroom. Education, 130(2), 241.

Richardson, V. (1997). Constructivist teaching and teacher education: Theory and practice. In V. Richardson, Constructivist teacher education: Building a world of new understandings, pp. 3-14. The Falmer Press.

Sadik, A. (2008). Digital storytelling: A meaningful technology-integrated approach for engaged student learning. Educational Technology Research and Development, 56(4), 487-506.

Schunk, D. H. (1996). Learning theories. New Jersey: Prentice Hall.

Sheikh, A., \& Mahmood, N. (2014). Effect of different teaching styles on students' motivation towards English language learning at secondary level. Science International (Labore), 26(20), 825-830.

Singer, F. M., \& Moscovici, H. (2008). Teaching and learning cycles in a constructivist approach to instruction. Teaching and Lecturer Education, 24(6), 1613-1634.

Summers, J. J., Waigandt, A., \& Whittaker, T. A. (2005). A comparison of student achievement and satisfaction in an online versus a traditional face-to-face statistics class. Innovative Higher Education, 29(3), 233-250.

Vygotsky, L. S. (1929). The problem of the cultural development of the child. Journal of Genetic Psychology, 36, 414-434.

Wadsworth, B. J. (1996). Piaget's theory of cognitive and affective development: Foundations of constructivism. Longman Publishing.

Witfelt, C. (2000). Educational multimedia and teachers' needs for new competencies: a study of compulsory school teachers' needs for competence to use educational multimedia. Educational Media International, 37(4), 235-241. 


\section{BIOGRAPHIES}

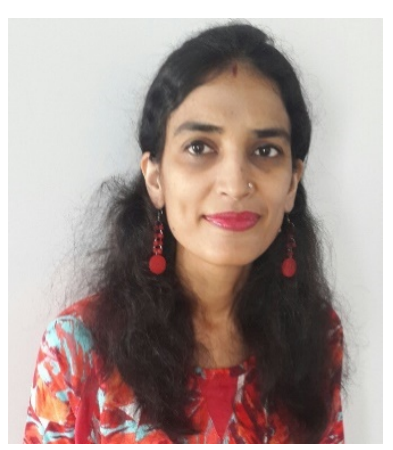

Greeni Maheshwari is a Bachelor of Engineering graduate from Maharaja Sayajirao University, India; PGDBA (Finance) from SCDL, India and pursing Doctorate of Business Administration (Global Business and Leadership) from California Intercontinental University, USA since November 2014. She joined RMIT in 2008 and has been involved in teaching courses in Quantitative Methods. Greeni has won three teaching awards in year 2016 at RMIT University, Vietnam for Excellence in Teaching and Learning.

Greeni has been awarded two gold medals from Maharaja Sayajirao University, India in Bachelor of Engineering for securing highest marks in final year as well for being the topper in all the four years of Engineering. She has been also awarded two silver medals by Institution of Engineers for securing the highest marks in Bachelor of Engineering along with the life-time free membership.

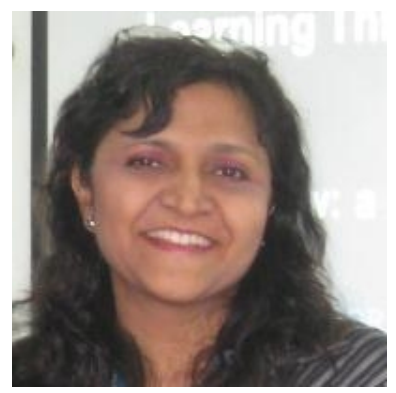

Associate Professor Susan Thomas is the Deputy Head of Centre Commerce and Management, RMIT University Vietnam. She received her PhD from University Malaysia and holds dual teaching qualifications from UK and Malaysia. She has more than 20 years teaching experience and has designed more than 200 workshops for Academic Professional Development. She received several awards in teaching and learning, amongst which are Pro Vice Chancellor Award for Teaching, Pro Vice Chancellor Award for Administration, International Graduate Scholar Award, and Best Paper Presented in a Conference. She worked as an International Consultant for World Bank Project to improve quality of education in third world countries. She is a member of the Qualitative Research Association of Malaysia (QRAM) and has published in top tiered journal in the field of education, health care and management. She continues to pursue her passion in community service education, student engagement and development and leadership in higher education. 